\title{
In vivo amelioration of aflatoxin B1 in broiler chicks by magnetic carbon nanocomposite ${ }^{1}$
}

\author{
Roheena Zafar², Farhat Ali Khan ${ }^{3}$ and Muhammad Zahoor ${ }^{4 *}$
}

\begin{abstract}
Zafar R., Khan F.A. \& Zahoor M. 2017. In vivo amelioration of aflatoxin B1 in broiler chicks by magnetic carbon nanocomposite. Pesquisa Veterinária Brasileira 37(11):1213-1219. Department of Chemistry, University of Malakand, Chakdara, Dir Lower, 18800 KPK, Pakistan.E-mail: mohammadzahoorus@yahoo.com

In this study an Iron oxide/carbon nanocomposite from maize straw was prepared and was characterized by XRD, SEM, EDX, FTIR, TG/DTA and Surface area analyzer. The adsorbent was fed to different groups of poultry birds along with aflatoxin B1. Different physiological and blood parameters were monitored in order to study the efficacy of the prepared adsorbent for binding of aflatoxin B1 in the gastrointestinal tract of chickens. It was found that adsorbent at dose of $0.3 \% / \mathrm{kg}$ feed was highly effective in detoxifying aflatoxin B1 in gastrointestinal tract of poultry birdswith no harmful effects. The high doses given to groups $\mathrm{E}$ and $\mathrm{F} ; 0.4 \%$ and $0.5 \%$ respectively showed slight variation in tested parameters from group A. No negative symptoms associated with the use of activated carbon as previously reported were observed for the adsorbent under study.
\end{abstract}

INDEX TERMS: Aflatoxin, poultry, alanine transferase, alkaline phosphatase

\section{INTRODUCTION}

Aflatoxins are the mycotoxin produced by different species of Aspergillus, causing aflatoxicoses in poultry birds that lowers their growth rate, increase weight loss and induce anorexia. Among aflatoxins, aflatoxin $\mathrm{B} 1\left(\mathrm{C}_{17} \mathrm{H}_{12} \mathrm{O}_{6}\right)$ is of predominant importance. Contamination of aflatoxin $\mathrm{B} 1$ in poultry and animal feed stuffs presents the highest toxic potential due to teratogenicity, carcinogenicity and mutagenicity (Huwig 2001).

A number of chemical, biological and physical methods have been used to detoxify aflatoxin contaminated food and feed stuff. Most of them are costly and time consuming (Bhatti et al. 2001). The most practical approach for detoxifying aflatoxins in poultry feed is the use of adsorbent (Huwig et al. 2001). Adsorbent bind aflatoxins and inhibit their absorption from gastrointestinal tract (Kannewischer et al. 2006). Most of the adsorbents have established effectiveness but their large quantities and negative interaction with nutrients are causes of great concern. The activated

\footnotetext{
${ }^{1}$ Received on July 29, 2016.

Accepted for publication on February 14, 2017.

${ }^{2}$ Department of Pharmacy, Sarhad University of Science \& Information Technology, Peshawar KPK, 23000, Pakistan. E-mail: zroheena@gmail.com

${ }^{3}$ Principal Abbotabad International College of Pharmacy AIMI, Abbotabad, KPK, Pakistan. E-mail: farhatkhan2k9@yahoo.com

${ }^{4}$ Department of Chemistry, University of Malakand, Chakdara, Dir Lower, 18800 KPK, Pakistan. *Corresponding author: mohammadzahoorus@yahoo.com
}

carbon is considered as efficient adsorbent. By virtue of its high surface area and porous structure it can remove organic compounds dispersed or dissolved in liquids. However this adsorbent causes dehydration and weight loss if fed to poultry (Peraica et al. 2002).

If small particle iron oxide is deposited on the surface of activated carbon, it will allow rapid adsorption on one hand and easy handing through magnetic process on the other hand (Oliveira et al. 2000).

The present study was aimed to prepare magnetic carbon nanostructures and evaluate it for the detoxification of aflatoxin B1 in the gastrointestinal tract of broiler chicks.

\section{MATERIALS AND METHOD}

Iron oxide carbon nanocomposite was prepared from maize straw and characterized as reported in our previous work. A specially designed chamber shown in Fig.1 was used for the preparation of novel adsorbent (Zahoor \& Farhat 2015).

The preparation of basal feed free from toxins were purchased from feed mill. Aflatoxin B1 was produced by culturing A. flavous on rice following the method of Shot Well (Ortatatli \& Oguz 2001). The Aflatoxin B1 residues produced were suspended into poly ethylene glycol and the required quantities were evenly mixed with basal feeds to get different level of aflatoxin B1contaminated feed samples.

In order to check the efficacy of the prepared adsorbent it was also fed to poultry birds along with contaminated feed for the detoxification of aflatoxin B1. Different physiological and clinical symptoms were monitored to evaluate the effectiveness of the adsorbent. 
All animals' experiments were carried out according to the rules and regulations of animal ethics committee, at the University of Malakand (Pakistan). A total of 480 one day old broiler chicks were purchased from local hatchery (Rawalpendi, Pakistan) and were kept in poultry house under standard environmental conditions. All these chicks were then equally divided into six different groups (A-F) and given access to fresh water and libitum for six weeks:

Group A. Chicks were kept on normal feed.

Group B. Chicks were kept on Aflatoxin B1 contaminated.

Group C. Chicks were given Aflatoxin B1 contaminated feed mixed with $0.2 \%$ of adsorbent.

Group D. Chicks were given Aflatoxin B1 contaminated feed mixed with $0.3 \%$ of adsorbent.

Group E. Chicks were given Aflatoxin B1 contaminated feed mixed with $0.4 \%$ of adsorbent.

Group F. Chicks were given Aflatoxin B1 contaminated feed mixed with $0.5 \%$ of adsorbent.

The body weights and mortality of the checks were recorded at the end of every week, while blood serum biochemistry for alanine transferase, alkaline phosphatase, albumen, globulin and total protein were carried out by collecting blood of 3 chicks individually from each group at the end of $1^{\text {st }}$ to $6^{\text {th }}$ weeks.

Clinical signs and behavior of chicks given different levels of adsorbent were evaluated by scoring 0 to 3 based upon (0) absence, (1) mild, (2) moderate and (3) maximum.

At the end of each experimental week three chicks were individually weighed and sacrificed from each group by cervical dislocation. Different organs were weighed to determined relative weight. The liver, kidney and heart were collected and were examined for gross lesion.

The data were analyzed for descriptive statistics, analysis of

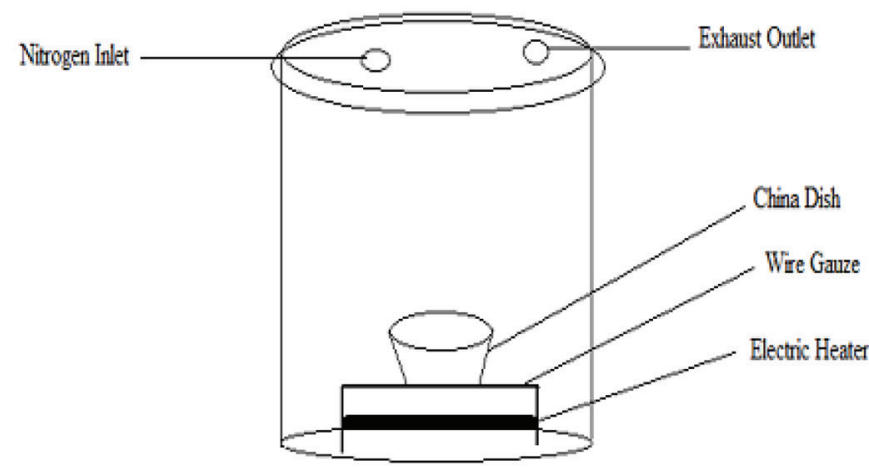

Fig.1. Diagram of chamber used for preparation of Iron oxide carbon nanocomposites. variance tests and LSD (Least significant difference). All pair wise comparisons test using STATISTIX 8.1 package. The data were considered significantly different at $\mathrm{P}$-value $\leq 0.05$.

\section{RESULTS AND DISCUSSION}

Prevention of aflatoxin contamination in feed is very important but when contamination occurs, decontamination of feed is needed before using it. Feasible, large scale production and economically efficient methods for remediation of aflatoxin in feeds is need of the day.

Iron oxide carbon nanocomposite were prepared from maize straw in specially designed chamber (Fig.1). The prepared Iron oxide carbon nanocomposite were characterized through SEM and XRD (Fig.2). From our previous in vitro study; the equilibrium time determined, was $96 \mathrm{~min}$ for $200 \mathrm{ppm}$ at $\mathrm{pH} 3$ while $180 \mathrm{~min}$ at $\mathrm{pH} 7$ where nearly $90 \%$ of aflatoxin was removed from solution at equilibrium, while best fit was obtained with pseudo-first- order kinetics model. At $\mathrm{pH}$ value above 11, there was a decline in percent adsorption. $\Delta \mathrm{S}^{\circ}$ value was positive while that of $\Delta \mathrm{H}^{\circ}$ and $\Delta \mathrm{G}^{\circ}$ were negative. At high temperature $\left(60^{\circ} \mathrm{C}\right)$, $\Delta \mathrm{G}^{\circ}$ value was high as compared to that of at $30^{\circ} \mathrm{C}$ which showed that the adsorption process was favorable at high temperature (Muhammad \& Farhat 2016). In this study the prepared magnetic adsorbent was used as alternative of activated carbon for the detoxification of aflatoxin in poultry feed as the former cause dehydration and salt deficiencies when given to poultry birds.

\section{Clinical signs and behavior}

Broiler chicks in group A showed normal signs and behavior throughout experimental period. All the chicks showed normal behavior throughout the experiment (Table 1). The chicks were found active and alert upon taping of the cage. Feaces were observed normal and semisolid, while the feathers were noted shinny and clean. Groups $\mathrm{D}, \mathrm{E}$ and $\mathrm{F}$ chicks exhibited normal signs and behavior at the end of $1^{\text {st }}, 2^{\text {nd }}, 3^{\text {rd }}$ and $4^{\text {th }}$ weeks, whereas the intensity were increased at the end of $5^{\text {th }}$ and $6^{\text {th }}$ week. However the chicks in group D were remained normal throughout the experimental period with very slight change in alertness, feed and water intake as compared to chicks of group $\mathrm{E}$ and F. Group B exhibited abnormal signs and behavior. Depression were noted in chicks of group B and experienced less attraction toward feed, while water intake was increased throughout the end of experimental weeks. However the intensity of clinical signs and behavior were increased with
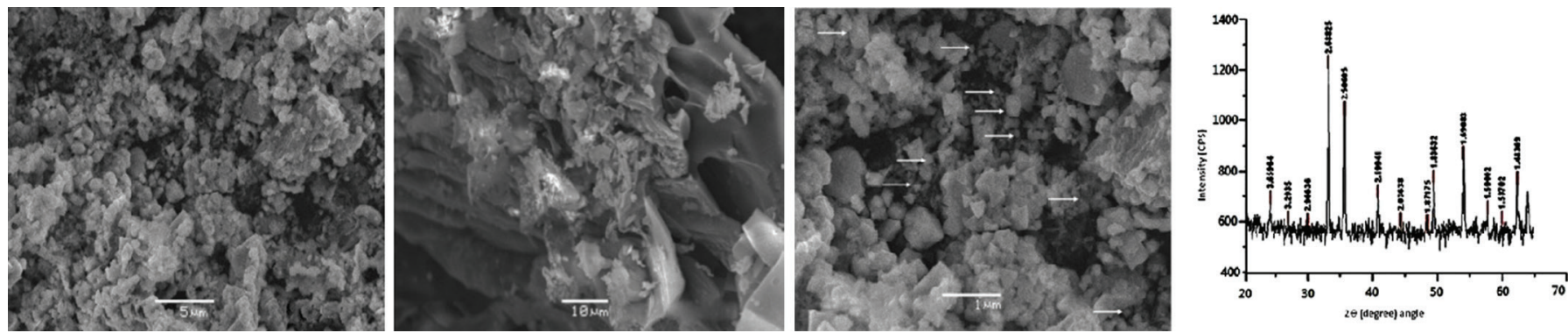

Fig.2. SEM images of iron oxide carbon nano composite prepared from maize straw at different magnification and XRD pattern of iron oxide carbon nano composite prepared from maize straw. 
Table 1. Clinical signs and behavior of poultry birds given different levels of adsorbent

\begin{tabular}{|c|c|c|c|c|c|c|c|c|}
\hline \multirow{3}{*}{$\begin{array}{l}\text { Time period } \\
\text { (Weeks) }\end{array}$} & \multirow[t]{3}{*}{ Clinical signs and behavior } & \multirow{3}{*}{$\begin{array}{c}\text { Range of } \\
\text { Score }\end{array}$} & \multicolumn{6}{|c|}{ Groups } \\
\hline & & & \multirow{2}{*}{$\frac{\text { Control }}{\mathrm{A}}$} & \multicolumn{5}{|c|}{ Aflatoxin B1 200 $\mu \mathrm{g} / \mathrm{kg}$ feed } \\
\hline & & & & $\mathrm{B}$ & $\mathrm{C}$ & $\mathrm{D}$ & $\mathrm{E}$ & $\mathrm{F}$ \\
\hline \multirow[t]{6}{*}{1} & Alertness normal-depressed & $0-3$ & 0 & 2 & 0 & 0 & 0 & 0 \\
\hline & Attraction to feed normal-less interest & $0-3$ & 0 & 5 & 0 & 0 & 0 & 0 \\
\hline & Attraction to water normal-more/less interest & $0-3$ & 0 & 11 & 0 & 0 & 0 & 0 \\
\hline & Faeces consistency normal-watery & $0-3$ & 0 & 5 & 0 & 0 & 0 & 0 \\
\hline & Feather normal-ruffled and broken & $0-3$ & 0 & 0 & 0 & 0 & 0 & 0 \\
\hline & Cumulative Score & 0 & 23 & 0 & 0 & 0 & 0 & \\
\hline \multirow[t]{6}{*}{2} & Alertness normal-depressed & $0-3$ & 0 & 5 & 0 & 0 & 0 & 0 \\
\hline & Attraction to feed normal-less interest & $0-3$ & 0 & 8 & 0 & 0 & 0 & 0 \\
\hline & Attraction to water normal-more/less interest & $0-3$ & 0 & 21 & 1 & 0 & 0 & 0 \\
\hline & Faeces consistency normal-watery & $0-3$ & 0 & 13 & 3 & 0 & 0 & 0 \\
\hline & Feather normal-ruffled and broken & $0-3$ & 0 & 0 & 0 & 0 & 0 & 0 \\
\hline & Cumulative Score & 0 & 47 & 4 & 0 & 0 & 0 & \\
\hline \multirow[t]{6}{*}{3} & Alertness normal-depressed & $0-3$ & 0 & 7 & 1 & 0 & 0 & 0 \\
\hline & Attraction to feed normal-less interest & $0-3$ & 0 & 12 & 1 & 0 & 0 & 0 \\
\hline & Attraction to water normal-more/less interest & $0-3$ & 0 & 34 & 2 & 0 & 0 & \\
\hline & Faeces consistency normal-watery & $0-3$ & 0 & 28 & 4 & 0 & 0 & 0 \\
\hline & Feather normal-ruffled and broken & $0-3$ & 0 & 0 & 0 & 0 & 0 & 0 \\
\hline & Cumulative Score & 0 & 81 & 8 & 0 & 0 & 0 & \\
\hline \multirow[t]{6}{*}{4} & Alertness normal-depressed & $0-3$ & 0 & 11 & 1 & 0 & 1 & 1 \\
\hline & Attraction to feed normal-less interest & $0-3$ & 0 & 29 & 2 & 0 & 0 & 0 \\
\hline & Attraction to water normal-more/less interest & $0-3$ & 0 & 51 & 4 & 0 & 0 & 0 \\
\hline & Faeces consistency normal-watery & $0-3$ & 0 & 41 & 6 & & 0 & 0 \\
\hline & Feather normal-ruffled and broken & $0-3$ & 0 & 0 & 0 & 0 & 0 & 0 \\
\hline & Cumulative Score & 0 & 132 & 13 & 0 & 1 & 1 & \\
\hline \multirow[t]{6}{*}{5} & Alertness normal-depressed & $0-3$ & 0 & 15 & 2 & 1 & 1 & 1 \\
\hline & Attraction to feed normal-less interest & $0-3$ & 0 & 48 & 4 & 0 & 1 & 1 \\
\hline & Attraction to water normal-more/less interest & $0-3$ & 0 & 72 & 6 & 0 & 1 & 2 \\
\hline & Faeces consistency normal-watery & $0-3$ & 0 & 62 & 9 & 0 & 0 & 2 \\
\hline & Feather normal-ruffled and broken & $0-3$ & 0 & 0 & 0 & 0 & 0 & 0 \\
\hline & Cumulative Score & 0 & 197 & 22 & 1 & 3 & 8 & \\
\hline \multirow[t]{7}{*}{6} & Alertness normal-depressed & $0-3$ & 0 & 18 & 3 & 1 & 3 & 3 \\
\hline & Attraction to feed normal-less interest & $0-3$ & 0 & 71 & 5 & 1 & 2 & 3 \\
\hline & Attraction to water normal-more/less interest & $0-3$ & 0 & 87 & 8 & 1 & 2 & 2 \\
\hline & Faeces consistency normal-watery & $0-3$ & 0 & 85 & 10 & 0 & 0 & 1 \\
\hline & Feather normal-ruffled and broken & $0-3$ & 0 & 13 & 3 & 0 & 0 & 2 \\
\hline & Cumulative Sore & 0 & & 274 & 29 & 3 & 7 & 11 \\
\hline & Total Cumulative Score & & & 754 & 178 & 28 & 70 & 91 \\
\hline
\end{tabular}

the passage of experimental period. Feathers condition remained normal at the end of 5 th week and became dull and dirty at the end of $6^{\text {th }}$ week. Chicks in group C showed normal signs and behavior. All the chicks rushed toward feed and water, the feaces were normal, while the feathers were clean and shiny at the end of $1^{\text {st }}$ week. The $2^{\text {nd }}$ week results were almost same as that of $1^{\text {st }}$ week with a little difference in the water intake and feaces consistency, though intensity of signs and behavior increased with the increase of experimental weeks. According to Chohota et al. (2000) the decrease in feed intake and increase in water intake may be due to avoid dehydration and replenish the water loss during watery and loose dropping.

\section{Blood serum biochemical parameters}

Alanine transferase (ALT). Weekly results of Blood serum biochemical parameters of poultry birds are given in Table 2. The blood serum biochemical analysis of broiler checks showed that the concentration of ALT of groups $\mathrm{D}, \mathrm{E}$ and $\mathrm{F}$ were significantly lower than groups $\mathrm{B}$ and C throughout the course of experiments. The values of group C were significantly higher than that of groups D, E and F, and lower than group B. The ALT concentrations of chicks of groups D, E and F were not significantly different, while the lowest values were recorded in groups $\mathrm{D}$ and $\mathrm{E}$.

Alkaline phosphatase (ALP. Alkaline Phosphatase concentration of broiler chicks of groups C, D, E and F were significantly lower than that of groups, while ALP concentrations was not significantly different to that of group D, E and $\mathrm{F}$. However the lowest values were observed in groups $\mathrm{E}$ and $\mathrm{F}$. The values of group $\mathrm{C}$ were found significantly lower than that of group F. D, E and F throughout the experimental weeks.

Serum albumen. Serum albumen values of group $C$ were significantly higher than group $B$, while lowered than that of groups D, E and F throughout all weeks. However no significant difference were found in serum albumen concentrations of chicks of groups D, E and F, while higher values were recorded in group.

Total protein. The concentration of Total protein in blood serum of checks of groups D, E and F were not significantly different, while the values of Total protein in group $\mathrm{C}$ were noted significantly different at the end of $1^{\text {st }}, 2^{\text {nd }}$ and $6^{\text {th }}$ week. However total protein concentrations of groups C, D, E and F were significantly higher than that of group B. The highest Total protein values were recorded in group $\mathrm{E}$. 
Table 2. Blood serum biochemical parameters of poultry birds given different dietary levels of adsorbent

\begin{tabular}{|c|c|c|c|c|c|c|c|}
\hline \multirow{3}{*}{$\begin{array}{l}\text { Time period } \\
\text { (Weeks) }\end{array}$} & \multirow{3}{*}{$\begin{array}{c}\text { Blood serum } \\
\text { parameter }\end{array}$} & \multicolumn{6}{|c|}{ Groups } \\
\hline & & \multirow{2}{*}{$\begin{array}{c}\text { Control } \\
\mathrm{A}\end{array}$} & \multicolumn{4}{|c|}{ Aflatoxin B1 200 $\mu \mathrm{g} / \mathrm{kg}$ feed } & \multirow[b]{2}{*}{$\mathrm{F}$} \\
\hline & & & B & $\mathrm{C}$ & $\mathrm{D}$ & $\mathrm{E}$ & \\
\hline \multirow[t]{5}{*}{1} & Alanine transferase & $16.10^{c} \pm 0.03$ & $18.15^{\mathrm{a}} \pm 0.27$ & $17.23^{\mathrm{b}} \pm 9.54$ & $16.18^{\mathrm{c}} \pm 0.24$ & $16.12^{\mathrm{c}} \pm 0.89$ & $16.24^{\mathrm{c}} \pm 0.27$ \\
\hline & Alkaline phosphat-ase & $629.75^{b} \pm 9.90$ & $662.27^{\mathrm{a}} \pm 5.68$ & $647.91^{\mathrm{ab}} \pm 20.02$ & $631.81^{b} \pm 6.95$ & $630.77^{b} \pm 10.76$ & $632.31^{\mathrm{b}} \pm 5.17$ \\
\hline & Serum albumen & $2.79^{\mathrm{a}} \pm 0.091$ & $2.43^{c} \pm 0.052$ & $2.63^{\mathrm{b}} \pm 0.069$ & $2.74^{\mathrm{a}} \pm 0.043$ & $2.73^{\mathrm{a}} \pm 0.030$ & $2.73^{\mathrm{a}} \pm 0.010$ \\
\hline & Serum total proteins & $3.25^{\mathrm{a}} \pm 0.045$ & $3.03^{c} \pm 0.010$ & $3.14^{\mathrm{b}} \pm 0.040$ & $3.23^{\mathrm{a}} \pm 0.060$ & $3.22^{\mathrm{ab}} \pm 0.052$ & $3.21^{\mathrm{ab}} \pm 0.025$ \\
\hline & Serum globulin & $0.740^{\mathrm{a}} \pm 0.052$ & $0.580^{\mathrm{b}} \pm 0.036$ & $0.690^{\mathrm{a}} \pm 0.036$ & $0.730^{\mathrm{a}} \pm 0.062$ & $0.710^{\mathrm{a}} \pm 0.030$ & $0.700^{\mathrm{a}} \pm 0.055$ \\
\hline \multirow[t]{5}{*}{2} & Alanine transferase & $16.33^{c} \pm 0.80$ & $19.43^{\mathrm{a}} \pm 0.26$ & $17.48^{\mathrm{b}} \pm 0.53$ & $16.40^{c} \pm 0.10$ & $16.67^{b c} \pm 0.07$ & $16.39^{c} \pm 0.60$ \\
\hline & Alkaline phosphatase & $630.62^{\mathrm{c}} \pm 14.16$ & $661.89^{\mathrm{a}} \pm 6.00$ & $643.97^{b} \pm 4.56$ & $631.80^{\mathrm{bc}} \pm 3.13$ & $632.32^{\mathrm{bc}} \pm 4.04$ & $633.45^{\mathrm{bc}} \pm 5.24$ \\
\hline & Serum albumen & $2.74^{\mathrm{a}} \pm 0.036$ & $2.40^{c} \pm 0.045$ & $2.61^{\mathrm{b}} \pm 0.070$ & $2.72^{\mathrm{a}} \pm 0.030$ & $2.67^{\mathrm{ab}} \pm 0.060$ & $2.71^{\mathrm{a}} \pm 0.017$ \\
\hline & Serum total proteins & $3.61^{\mathrm{a}} \pm 0.050$ & $3.14^{\mathrm{c}} \pm 0.040$ & $3.35^{b} \pm 0.026$ & $3.57^{\mathrm{a}} \pm 0.030$ & $3.53^{\mathrm{a}} \pm 0.072$ & $3.53^{\mathrm{a}} \pm 0.055$ \\
\hline & Serum globulin & $0.680^{\mathrm{a}} \pm 0.020$ & $0.400^{c} \pm 0.045$ & $0.566^{\mathrm{b}} \pm 0.015$ & $0.666^{\mathrm{a}} \pm 0.066$ & $0.660^{\mathrm{ab}} \pm 0.070$ & $0.650^{\mathrm{ab}} \pm 0.070$ \\
\hline \multirow[t]{5}{*}{3} & Alanine transferase & $15.93^{c} \pm 0.21$ & $22.54^{\mathrm{a}} \pm 1.98$ & $17.53^{\mathrm{b}} \pm 0.18$ & $15.97^{c} \pm 0.13$ & $16.02^{\mathrm{c}} \pm 0.08$ & $16.18^{\mathrm{bc}} \pm 0.34$ \\
\hline & Alkaline phosphatase & $625.35^{c} \pm 13.55$ & $684.77^{\mathrm{a}} \pm 11.33$ & $645.39^{b} \pm 8.02$ & $625.98^{c} \pm 12.89$ & $625.77^{c} \pm 10.65$ & $625.81^{c} \pm 6.85$ \\
\hline & Serum albumen & $2.71^{\mathrm{a}} \pm 0.026$ & $2.36 \mathrm{~d} \pm 0.017$ & $2.51^{\mathrm{c}} \pm 0.010$ & $2.68^{\mathrm{ab}} \pm 0.026$ & $2.65^{\mathrm{b}} \pm 0.010$ & $2.66^{\mathrm{b}} \pm 0.026$ \\
\hline & Serum total proteins & $3.55^{\mathrm{a}} \pm 0.050$ & $3.13^{c} \pm 0.121$ & $3.39^{b} \pm 0.130$ & $3.51^{\mathrm{ab}} \pm 0.020$ & $3.50^{\mathrm{ab}} \pm 0.062$ & $3.49^{\mathrm{ab}} \pm 0.026$ \\
\hline & Serum globulin & $0.820^{\mathrm{a}} \pm 0.020$ & $0.410^{c} \pm 0.050$ & $0.700^{\mathrm{b}} \pm 0.045$ & $0.780^{\mathrm{a}} \pm 0.036$ & $0.776^{\mathrm{a}} \pm 0.030$ & $0.750^{\mathrm{ab}} \pm 0.065$ \\
\hline \multirow[t]{5}{*}{4} & Alanine transferase & $16.51^{\mathrm{c}} \pm 0.53$ & $26.72^{\mathrm{a}} \pm 1.51$ & $19.12^{\mathrm{b}} \pm 0.21$ & $16.75^{c} \pm 0.55$ & $16.74^{\mathrm{c}} \pm 0.22$ & $16.84^{c} \pm 0.25$ \\
\hline & Alkaline phosphatase & $643.52^{\mathrm{b}} \pm 4.77$ & $832.32^{\mathrm{a}} \pm 21.42$ & $719.77^{\mathrm{b}} \pm 23.21$ & $644.25^{\mathrm{b}} \pm 2.72$ & $644.71^{\mathrm{b}} \pm 4.39$ & $645.67^{\mathrm{b}} \pm 4.06$ \\
\hline & Serum albumen & $2.73^{\mathrm{a}} \pm 0.043$ & $2.21^{\mathrm{c}} \pm 0.050$ & $2.59^{\mathrm{b}} \pm 0.043$ & $2.71^{\mathrm{a}} \pm 0.036$ & $2.69^{\mathrm{a}} \pm 0.030$ & $2.68^{\mathrm{a}} \pm 0.020$ \\
\hline & Serum total proteins & $3.35^{\mathrm{a}} \pm 0.043$ & $2.80^{\mathrm{b}} \pm 0.048$ & $3.07^{\mathrm{ab}} \pm 0.058$ & $3.34^{\mathrm{a}} \pm 0.101$ & $3.32^{\mathrm{a}} \pm 0.045$ & $3.32^{\mathrm{a}} \pm 0.075$ \\
\hline & Serum globulin & $0.700^{\mathrm{a}} \pm 0.062$ & $0.380^{c} \pm 0.026$ & $0.573^{\mathrm{b}} \pm 0.032$ & $0.670^{\mathrm{ab}} \pm 0.104$ & $0.690^{\mathrm{a}} \pm 0.080$ & $0.680^{\mathrm{ab}} \pm 0.052$ \\
\hline \multirow[t]{5}{*}{5} & Alanine transferase & $16.40^{c} \pm 0.71$ & $36.03^{\mathrm{a}} \pm 3.63$ & $19.80^{\mathrm{b}} \pm 1.54$ & $16.42^{\mathrm{c}} \pm 0.56$ & $16.51^{\mathrm{c}} \pm 0.40$ & $16.48^{c} \pm 0.58$ \\
\hline & Alkaline phosphatase & $637.88^{c} \pm 12.95$ & $1060^{\mathrm{a}} \pm 38.16$ & $781.59^{\mathrm{b}} \pm 18.88$ & $639.06^{c} \pm 6.58$ & $640.16^{\mathrm{c}} \pm 1.84$ & $645.13^{c} \pm 9.32$ \\
\hline & Serum albumen & $2.78^{\mathrm{a}} \pm 0.017$ & $2.16^{\mathrm{c}} \pm 0.026$ & $2.72^{\mathrm{b}} \pm 0.010$ & $2.76^{\mathrm{a}} \pm 0.026$ & $2.76^{\mathrm{a}} \pm 0.017$ & $2.75^{\mathrm{ab}} \pm 0.010$ \\
\hline & Serum total proteins & $3.48^{\mathrm{a}} \pm 0.105$ & $2.90^{\mathrm{b}} \pm 0.32$ & $3.27^{\mathrm{a}} \pm 0.107$ & $3.48^{\mathrm{a}} \pm 0.070$ & $3.45^{\mathrm{a}} \pm 0.095$ & $3.45^{\mathrm{a}} \pm 0.085$ \\
\hline & Serum globulin & $0.670^{\mathrm{a}} \pm 0.045$ & $0.360^{c} \pm 0.70$ & $0.576^{\mathrm{b}} \pm 0.011$ & $0.660^{\mathrm{ab}} \pm 0.078$ & $0.630^{\mathrm{ab}} \pm 0.030$ & $0.660^{\mathrm{ab}} \pm 0.043$ \\
\hline \multirow[t]{5}{*}{6} & Alanine transferase & $16.21^{\mathrm{c}} \pm 0.17$ & $59.79^{\mathrm{a}} \pm 4.44$ & $23.61^{\mathrm{b}} \pm 2.09$ & $16.37^{c} \pm 0.27$ & $16.31^{\mathrm{c}} \pm 0.33$ & $16.35^{c} \pm 0.15$ \\
\hline & Alkaline phosphatase & $641.46^{c} \pm 3.39$ & $1219^{\mathrm{a}} \pm 38.77$ & $773.17^{\mathrm{b}} \pm 18.74$ & $653.53^{c} \pm 14.24$ & $652.23^{c} \pm 4.76$ & $654.13^{c} \pm 10.69$ \\
\hline & Serum albumen & $2.77^{\mathrm{a}} \pm 0.026$ & $2.09^{c} \pm 0.052$ & $2.67^{\mathrm{b}} \pm 0.075$ & $2.76^{\mathrm{a}} \pm 0.035$ & $2.76^{\mathrm{a}} \pm 0.020$ & $2.75^{\mathrm{a}} \pm 0.034$ \\
\hline & Serum total proteins & $3.53^{\mathrm{a}} \pm 0.098$ & $2.97^{c} \pm 0.065$ & $3.35^{b} \pm 0.030$ & $3.52^{\mathrm{a}} \pm 0.034$ & $3.49^{\mathrm{a}} \pm 0.098$ & $3.47^{\mathrm{ab}} \pm 0.075$ \\
\hline & Serum globulin & $0.680^{a} \pm 0.078$ & $0.340^{c} \pm 0.030$ & $0.546^{\mathrm{b}} \pm 0.032$ & $0.670^{\mathrm{a}} \pm 0.072$ & $0.660^{\mathrm{a}} \pm 0.065$ & $0.650^{\mathrm{a}} \pm 0.045$ \\
\hline
\end{tabular}

Serum globulin. Biochemical Blood serum analysis showed that the concentration of Serum globulin of broiler checks of group $\mathrm{C}$ were significantly higher than group B, while significantly less than that of groups D, E and F at the end of week $2^{\text {nd }}, 3^{\text {rd }}$ and $6^{\text {th }}$. The values of Serum globulin in groups $\mathrm{D}, \mathrm{E}$ and $\mathrm{F}$ were not significantly different; however the higher values of Serum globulin were recorded in group D.

Serum biochemical parameters such as total protein, serum globulin, albumen contents, alkaline phosphatase and ALT activities represents hepatic malfunctioning or liver injury (Abbès et al. 2006, Mathur et al. 2001).

\section{Mortality}

Table 3 represents mortalities of poultry birds during experiments. Mortality rate in the groups A, C, D, E and $\mathrm{F}$ was $0 \%$ throughout the experimental period while for group B, it was 2 at the end of $6^{\text {th }}$ week.

\section{Body weights}

Weekly results of Body weights of poultry birds are shown in Table 4. There was no significant difference in the body weight values of groups $A$ and $D$, while a significant difference was observed in the values of group $\mathrm{A}$ and $\mathrm{C}$ at the end of $3^{\text {rd }}, 4^{\text {th }}, 5^{\text {th }}$ and $6^{\text {th }}$ weeks. However the values of groups $\mathrm{C}, \mathrm{D}, \mathrm{E}$ and $\mathrm{F}$ were significantly higher than group $B$. The maximum values were recorded in group D. In the present study it was noted that the body weight of chicks decreased when fed on aflatoxin contaminated feed as previously reported by many workers (Miazzo et al., 2005).
Table 3. Relative \% mortality of poultry birds given different levels of adsorbent

\begin{tabular}{|c|c|c|c|c|c|c|}
\hline \multirow{3}{*}{$\begin{array}{l}\text { Time period } \\
\text { (Weeks) }\end{array}$} & \multicolumn{6}{|c|}{ Groups } \\
\hline & \multirow{2}{*}{$\begin{array}{c}\text { Control } \\
\mathrm{A}\end{array}$} & \multicolumn{5}{|c|}{ Aflatoxin B1 $200 \mu \mathrm{g} / \mathrm{kg}$ feed } \\
\hline & & $\mathrm{B}$ & $\mathrm{C}$ & $\mathrm{D}$ & $\mathrm{E}$ & $\mathrm{F}$ \\
\hline 1 & 0 & 0 & 0 & 0 & 0 & 0 \\
\hline 2 & 0 & 0 & 0 & 0 & 0 & 0 \\
\hline 3 & 0 & 0 & 0 & 0 & 0 & 0 \\
\hline 4 & 0 & 0 & 0 & 0 & 0 & 0 \\
\hline 5 & 0 & 0 & 0 & 0 & 0 & 0 \\
\hline 6 & 0 & 2 & 0 & 0 & 0 & 0 \\
\hline Total mortality & 0 & 2 & 0 & 0 & 0 & 0 \\
\hline \%mortality & $0 \%$ & $3.07 \%$ & $0 \%$ & $0 \%$ & $0 \%$ & $0 \%$ \\
\hline
\end{tabular}

\section{Liver weight}

Relative weights of liver of broiler chicks (Table 4) in all groups were not significantly different at the end of week 1 . At conclusion of week 2, 3,4,5 and 6 no significant differences were observed in the values of groups A, C, d, E and F, while the values of group B were significantly higher than that of groups A, C, D, E and F. However lower values were recorded in group D as compared to groups $\mathrm{C}, \mathrm{E}$ and $\mathrm{F}$. The increase in relative weight of liver in group $\mathrm{B}$ may be due to deposition of fats in liver.

\section{Kidney weight}

Relative kidney weights of broiler chicks are shown in Table 4. The values of group B was found significantly higher than group $A$ at the end of $1^{\text {st }}$ and $2^{\text {nd }}$ week. Relative 
Table 4. Relative body (g) and organ weights (\%Body weight) of poultry birds given different levels of adsorbent

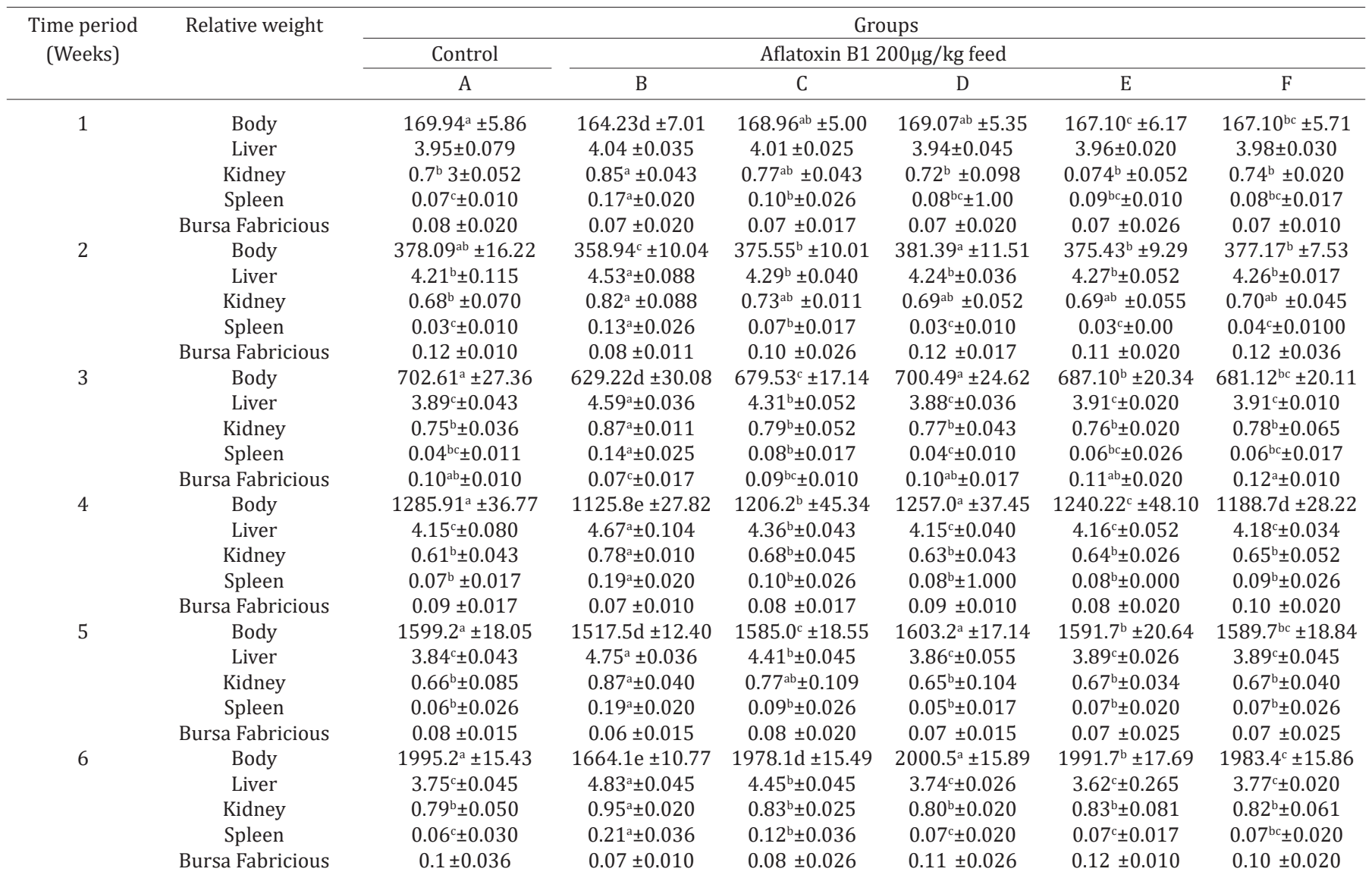

weight of kidneys of broiler chicks were noted non-significant in groups C, D, E and F at the end of $3^{\text {rd }}, 4^{\text {th }}, 5^{\text {th }}$ and $6^{\text {th }}$ week, however lower values were recorded in group D. The increased relative weights of kidney was probably due to slight renal damage. The results abstained were in agreements with previous study reported by Huff et al. (1992) in which he found that aflatoxin alone in feed increase the kidney weight whereas by addition of adsorbent to aflatoxin contaminated feed ameliorated the deleterious effects of aflatoxin in broiler chicks.

\section{Spleen weight}

Relative spleen weights (Table 4) were found significantly higher in group B, than that of groups C, D, E and F, while no significant difference were observed in the relative spleen weights of broiler chicks of groups C, D, E and F throughout the end of experimental weeks. The lower relative weight of spleen of broiler chicks given different levels of adsorbent was noted in group B. Our findings related to group B are in close accord to Hesham et al. (2004) in which the increase in relative spleen weight was due to the presences of aflatoxin in the diet.

\section{Weight of bursa of Fabricious}

Weekly Relative Bursa of fabricious weights of broiler chicks are presented in Table 4 . The values of relative weight of Bursa of fabricious of broiler chicks were observed non-significant in all groups (A, B, C, D, e and F) at the end of $1^{\text {st }}$ and $2^{\text {nd }}$ week, while significantly lower value was recorded in group $B$ and higher value in group $D$ at the end of $3^{\text {rd }}$ week. However no significant changes in the weight of Bursa of fabricious were noted at the end of remaining experimental weeks. The relative weights of Bursa were not affected by any dietary treatments, however contrary results have been reported by Thalij (2005).

\section{Hemorrhages in organs}

Weekly results of hemorrhages in different organs of broiler chicks are presented in Table 5. Gross morphology of different organs of chicks of group A and C were observed normal throughout the course of experiment. No hemorrhages were seen on liver, kidney and heart. However chicks of group B exhibited abnormality regarding hemorrhages on liver and kidney. Hemorrhages of liver started from $2^{\text {nd }}$ week whereas kidney in the $3^{\text {rd }}$ week. The intensity was found increased and maximum at the end of $6^{\text {th }}$ week. In case of group C mild hemorrhages were started from $4^{\text {th }}$ week and persisted till the end of $6^{\text {th }}$ week, while mild hemorrhages of kidney were noted at the end of $5^{\text {th }}$ and $6^{\text {th }}$ week.

Hemorrhages on different organs in broiler chicks during aflatoxicosis have also been reported by Ortatatli et al. (2005).

\section{Enlargement of organs}

Different organs of Chicks in group A were found normal in size and appearance during gross examina- 
tion throughout the course of experimental weeks (Table 6). Groups A and C showed that organs including liver, kidney and heart showed normal appearance and no enlargement were observed all over the length of study. In group B there were no change in size and appearance of liver, kidney and heart at the end of $1^{\text {st }}$ week whereas slight swelling of liver was observed at the end of $2^{\text {nd }}$ week. Scores of enlargement of liver and kidney increased with the passage of experimental weeks and recorded maximum at the end of $6^{\text {th }}$ week. However the heart was found normal in size and shape during experiments.

Our results also demonstrated that by adding different levels of adsorbent in aflatoxin contaminated feed ameliorated the hazardous effects of aflatoxin as previously reported by Raju and Devegoda (2000) and Ortatatli et al.

Table 5. Hemorrhages in organs of poultry birds given different levels of adsorbent

\begin{tabular}{|c|c|c|c|c|c|c|c|c|}
\hline \multirow{3}{*}{$\begin{array}{l}\text { Time period } \\
\text { (Weeks) }\end{array}$} & \multirow[t]{3}{*}{ Organs } & \multirow{3}{*}{$\begin{array}{c}\text { Maximum possible } \\
\text { score }\end{array}$} & \multicolumn{6}{|c|}{ Groups } \\
\hline & & & \multirow{2}{*}{$\begin{array}{c}\text { Control } \\
\mathrm{A}\end{array}$} & \multicolumn{5}{|c|}{ Aflatoxin B1 200 $\mu \mathrm{g} / \mathrm{kg}$} \\
\hline & & & & $\mathrm{B}$ & $\mathrm{C}$ & $\mathrm{D}$ & $\mathrm{E}$ & $\mathrm{F}$ \\
\hline \multirow[t]{4}{*}{1} & Liver & 9 & 0 & 0 & 0 & 0 & 0 & 0 \\
\hline & Kidney & 9 & 0 & 0 & 0 & 0 & 0 & 0 \\
\hline & Heart & 9 & 0 & 0 & 0 & 0 & 0 & 0 \\
\hline & Cumulative score & 27 & 0 & 0 & 0 & 0 & 0 & 0 \\
\hline \multirow[t]{4}{*}{2} & Liver & 9 & 0 & 3 & 0 & 0 & 0 & 0 \\
\hline & Kidney & 9 & 0 & 0 & 0 & 0 & 0 & 0 \\
\hline & Heart & 9 & 0 & 0 & 0 & 0 & 0 & 0 \\
\hline & Cumulative score & 27 & 0 & 3 & 0 & 0 & 0 & 0 \\
\hline \multirow[t]{4}{*}{3} & Liver & 9 & 0 & 4 & 0 & 0 & 0 & 0 \\
\hline & Kidney & 9 & 0 & 2 & 0 & 0 & 0 & 0 \\
\hline & Heart & 9 & 0 & 0 & 0 & 0 & 0 & 0 \\
\hline & Cumulative score & 27 & 0 & 6 & 0 & 0 & 0 & 0 \\
\hline \multirow[t]{4}{*}{4} & Liver & 9 & 0 & 6 & 2 & 0 & 0 & 0 \\
\hline & Kidney & 9 & 0 & 4 & 0 & 0 & 0 & 0 \\
\hline & Heart & 9 & 0 & 0 & 0 & 0 & 0 & 0 \\
\hline & Cumulative score & 27 & 0 & 10 & 2 & 0 & 0 & 0 \\
\hline \multirow[t]{4}{*}{5} & Liver & 9 & 0 & 7 & 2 & 0 & 0 & 1 \\
\hline & Kidney & 9 & 0 & 3 & 0 & 0 & 0 & 0 \\
\hline & Heart & 9 & 0 & 0 & 0 & 0 & 0 & 0 \\
\hline & Cumulative score & 27 & 0 & 10 & 2 & 0 & 0 & 1 \\
\hline \multirow[t]{4}{*}{6} & Liver & 9 & 0 & 7 & 2 & 0 & 1 & 1 \\
\hline & Kidney & 9 & 0 & 5 & 1 & 0 & 0 & 0 \\
\hline & Heart & 9 & 0 & 0 & 0 & 0 & 0 & 0 \\
\hline & Cumulative score & 27 & 0 & 12 & 3 & 0 & 1 & 1 \\
\hline
\end{tabular}

Table 6. Enlargement of organs of Poultry birds given different levels of adsorbent

\begin{tabular}{|c|c|c|c|c|c|c|c|c|}
\hline \multirow{3}{*}{$\begin{array}{l}\text { Time period } \\
\text { (Weeks) }\end{array}$} & \multirow[t]{3}{*}{ Organs } & \multirow{3}{*}{$\begin{array}{c}\text { Maximum possible } \\
\text { score }\end{array}$} & \multicolumn{6}{|c|}{ Groups } \\
\hline & & & \multirow{2}{*}{$\begin{array}{c}\text { Control } \\
\mathrm{A}\end{array}$} & \multicolumn{5}{|c|}{ Aflatoxin B1 200 $\mu \mathrm{g} / \mathrm{kg}$} \\
\hline & & & & $\mathrm{B}$ & $\mathrm{C}$ & $\mathrm{D}$ & $\mathrm{E}$ & $\mathrm{F}$ \\
\hline \multirow[t]{4}{*}{1} & Liver & 9 & 0 & 0 & 0 & 0 & 0 & 0 \\
\hline & Kidney & 9 & 0 & 0 & 0 & 0 & 0 & 0 \\
\hline & Heart & 9 & 0 & 0 & 0 & 0 & 0 & 0 \\
\hline & Cumulative score & 27 & 0 & 0 & 0 & 0 & 0 & 0 \\
\hline \multirow[t]{4}{*}{2} & Liver & 9 & 0 & 3 & 0 & 0 & 0 & 0 \\
\hline & Kidney & 9 & 0 & 0 & 0 & 0 & 0 & 0 \\
\hline & Heart & 9 & 0 & 0 & 0 & 0 & 0 & 0 \\
\hline & Cumulative score & 27 & 0 & 3 & 0 & 0 & 0 & 0 \\
\hline \multirow[t]{4}{*}{3} & Liver & 9 & 0 & 4 & 1 & 0 & 0 & 0 \\
\hline & Kidney & 9 & 0 & 1 & 0 & 0 & 0 & 0 \\
\hline & Heart & 9 & 0 & 0 & 0 & 0 & 0 & 0 \\
\hline & Cumulative score & 27 & 0 & 5 & 1 & 0 & 0 & 0 \\
\hline \multirow[t]{4}{*}{4} & Liver & 9 & 0 & 6 & 1 & 0 & 0 & 1 \\
\hline & Kidney & 9 & 0 & 2 & 0 & 0 & 0 & 0 \\
\hline & Heart & 9 & 0 & 0 & 0 & 0 & 0 & 0 \\
\hline & Cumulative score & 27 & 0 & 8 & 1 & 0 & 0 & 1 \\
\hline \multirow[t]{4}{*}{5} & Liver & 9 & 0 & 6 & 2 & 0 & 1 & 1 \\
\hline & Kidney & 9 & 0 & 3 & 0 & 0 & 0 & 0 \\
\hline & Heart & 9 & 0 & 0 & 0 & 0 & 0 & 0 \\
\hline & Cumulative score & 27 & 0 & 9 & 2 & 0 & 1 & 1 \\
\hline \multirow[t]{4}{*}{6} & Liver & 9 & 0 & 7 & 2 & 1 & 1 & 1 \\
\hline & Kidney & 9 & 0 & 3 & 1 & 0 & 0 & 0 \\
\hline & Heart & 9 & 0 & 0 & 0 & 0 & 0 & 0 \\
\hline & Cumulative score & 27 & 0 & 10 & 3 & 1 & 1 & 1 \\
\hline
\end{tabular}


(2005) in which they studied the ameliorating effects of different adsorbents in checks fed on aflatoxin contaminated feed.

\section{CONCLUSIONS}

The results indicated that the prepared adsorbent when mixed in $0.3 \% / \mathrm{kg}$ of feed is highly effective to adsorb aflatoxin B1 in gastrointestinal tract of poultry birds. However the results of groups $\mathrm{E}$ and $\mathrm{F}$ fed on $0.4 \%$ and $0.5 \%$ respectively showed slight variation in tested parameters from group A.

It is concluded that different levels of adsorbent in aflatoxin contaminated feed considerably ameliorated the hazardous effects of aflatoxin B1.

Conflict of interest disclosure.-The authors declare no competing financial interest.

Author's contributions.- All the author contributed equally in the present manuscript. All authors read and approved the final manuscript.

Acknowledgment.- The authors are thankful to PCSIR and HEC Pakistan for their financial support.

\section{REFERENCES}

Abbès S., Ouanes Z., Salah-Abbes J., Houas Z., Oueslati R., Bacha H. \& Othman 0.2006 . The protective effect of hydrated sodium calcium aluminosilicate against haematological, biochemical and pathological changes induced by Zearalenone in mice. Toxcion 47:567-574.

Bhatti B.M., Talat T. \& Sardar R. 2001. Estimation of aflatoxin B1 in feed ingredients and compound poultry feeds. Pak. Vet. J. 21:57-60.

Chohota R., Katoock R.C., Singh S.P., Verma S. \& Mahajan A. 2000. Concurrent outbreak of chlamydosis and aflatoxicosis among chickens in $\mathrm{Hi}$ maschal Pradesh. India Vet. Archiv 70:207-213.

Hesham M.T., Hegazy A.A. \& Yehia A.H. 2004. Efficiency of kaolin and acti- vated charcoal to reduce the toxicity of low level of aflatoxin in broilers. Scientific J. King Faisal University 5:14-25.

Huff W.E., Kubena L.F., Harvey R.B. \& Phillips T.D. 1992. Efficacy of hydrated sodium calcium aluminosilicate to reduce the individual and combined toxicity of aflatoxin and ochratoxin A. Poult. Sci. 71:64-69.

Huwig A., Friemud S., Kappeli O. \& Dutler H. 2001. Mycotoxin detoxification of animal feed by different adsorbents. Toxicol. Lett. 122:179-188.

Kannewischer I., Arvide M.T., Whiteand G.N. \& Dixon J.B. 2006. Smectite clays as adsorbents of aflatoxin B1: Initial steps. Clay Sci. 2:199-204.

Mathur S., Constable P.D. \& Eppley R.M. 2001. Fumonisin B1 is hepatotoxic and nephrotoxic in milk-fed calves. Toxicol. Sci. 60:385-396.

Miazzo R., Pevalta M.F., Magnoli C., Salvano M., Ferrero S., Chiacchiera S.M., Carralno E.C.Q., Rosa C.A.R. \& Dalcero A. 2005. Efficacy of sodium bentonite as a detoxifier of broiler fed contaminated with aflatoxin and fumonisin. Poult. Sci. 84:1-8.

Muhammad Z. \& Farhat A.K. 2016. Aflatoxin B1 Detoxification by Magnetic Carbon nanostructures Prepared from Maize straw. Des. Water Treat. 57:11893-11903.

Oliveira L.C.A., Rios R.A., Fabris J.D., Garg V., Sapag K. \& Lago R.M. 2000. Activated carbon/iron oxide magnetic composites for adsorption of contaminants in water. Carbon. 40:2177-2183.

Ortatatli M. \& Oguz H. 2001. Ameliorative effects of dietary clinoptilolite on pathological changes in poultry birdsduring aflatoxicoses. Res. Vet. Sci. 71:59-66.

Ortatatli M., Oguz H., Hatipog F. \& Karaman M. 2005. Evaluation of pathological changes in broiler during chronic aflatoxin and clinoptilite exposure. Res. Vet. Sci. 78:61-68.

Peraica M.A., Z. Domijan Z., Jurjevic Z. \& Cvjetkovic B. 2002. Prevention of exposure to mycotoxins from food and feed. Arch. Indust. Hygiene Toxicol. 53:229-237.

Raju M.V. \& Devegoda G. 2000. Influence of estrified-glucomanan on performance and organ morphology, serum biochemistry and hematology in broilers exposed to individual and combined mycotoxicosis(aflatoxin, ochratoxin and T-2 toxin). Brit. Poul. Sci. 14:640-650.

Thalij K.M. 2005. Efficacy of activated sodium bentonite to reduce the toxicity of aflatoxins and $\mathrm{t}-2$ toxin in broiler chicks. Mesopotamia J. Agric. 33(4):1-10. 